\title{
Evaluation of Tensile Bond Strength of Heat-Polymerized Acrylic Soft Liners with Various Surface Pre-Treatment of Denture Bases: An In Vitro Study
}

\author{
Hari kumar Mempally ${ }^{1}$, Jayasree Komala², Sri Guru Mangala Deepti Ganji ${ }^{2}$ \\ ${ }^{1}$ Department of Prosthodontics and Crown \& Bridge, Aditya Dental College, Beed, Maharashtra, India, ${ }^{2}$ Department of Prosthodontics \\ and Crown \& Bridge, SVS Institute of Dental Sciences, Mahbubnagar, Telangana, India
}

Email for correspondences: jayasreekomala@yahoo.com

\begin{abstract}
Background: Resilient liners are prone to bond failure with acrylic resin base, creating an environment for bacterial growth and accelerated break down of soft liner, resulting in a deteriorating prosthesis. Aims and Objectives: The purpose of the present study is to evaluate the efficacy of mechanical, chemical, and mechanochemical pre-treatment of denture base resin on the tensile bond strength of heat-cured permanent resilientliners. Materials and Methods: A total of 320 cuboidal blocks $(40 \mathrm{~mm} \times 10 \mathrm{~mm}$ x $10 \mathrm{~mm}$ ) of heat-polymerized acrylic resin (Trevalon) were made which were equally grouped into Permasoft (Group 1) and Acrasoft (Group 2). Each group was further subdivided into four subgroups based on surface pre-treatment of denture base, namely: Control, chemical (methyl methacrylate [MMA]), mechanical (sandblasting with $250 \mu$ aluminum oxide particles), and mechanochemical (sandblasting followed by MMA). A 3-mm thick resilient denture liner was packed between two resin blocks. Then, each subgroup was divided into two test groups $(n=10)$ for testing tensile bond strength (using universal testing machine) after $24 \mathrm{~h}$ and 30 days post-immersion in artificial saliva. One-way ANOVA and Tukey test were used for data analysis. Results: The tests resulted in greater tensile bond strength for Acrasoft group compared to Permasoft at both $24 \mathrm{~h}$ and 1 month. Between the two time periods, it was more for $24 \mathrm{~h}$ group. Among all methods, mechanical method resulted in superior tensile bond strength. Conclusion: This in vitro study concluded that all the tested pre-treatment methods showed better tensile bond strength than control group, maximum with mechanical group.
\end{abstract}

Key words: Denture liners, pre-treatment, tensile bond strength

\section{INTRODUCTION}

Preservation and maintenance of dental foundation tissues are of utmost importance in the field of prosthodontics. Several systemic and metabolic disorders greatly hamper the tissue response to functional loading after insertion of the

\begin{tabular}{|l|l|}
\hline Quick Response Code & Article Info: \\
\hline doi: 10.5866/2018.10.10065 \\
\hline $\begin{array}{l}\text { Received: } 28-05-2018 \\
\text { Revised: } 18-06-2018 \\
\text { Accepted: } 20-06-2018 \\
\text { Available Online:15-07-2018 (www. } \\
\text { nacd.in)@ NAD, } 2018 \text { - All rights reserved }\end{array}$ \\
\hline
\end{tabular}

prosthesis. As a result, multiple changes could be observed in the denture bearing hard and soft tissues consequently affecting masticatory function. ${ }^{[1]}$

The resilient lining materials are useful in removable prosthodontics because of their capability of restoring the health of inflamed mucosa, promoting more equal distribution of functional load on the denture foundation area, and also improving the fitting surface of the denture and retention of the prosthesis by engaging the undercut. ${ }^{[2,3]}$ However, resilient denture liners have several problems associated with their use, as loss of softness, change of permanent deformation characteristics, water absorption, and colonization 
by Candida albicans. In clinical practice, one of the most serious problems is the failure of adhesion between denture liners and the denture base. Bond failures result in bacterial growth, plaque, and calculus formation. Therefore, frequent clinical evaluation and periodic replacement of resilient denture liners are required. Ideally, denture liners should bond well to polymethyl methacrylate (PMMA) resin denture base to avoid interface failure during the service of the prosthesis. Relined dentures can only be successful if a satisfactory bond exists between the original denture base and the relining material.

To overcome this problem, several methods have been proposed to improve the adhesion between the liner and denture base which include various surface pre-treatment of the tissue surface of the denture base by chemical and mechanical modalities that have reported varying degrees of success. ${ }^{[4-9]}$ Various authors have suggested the use of organic solvents such as chloroform acetone, methyl methacrylate (MMA), and methyl chloride to increase the bond strength of resilient liner to denture base material. ${ }^{[5,8]}$ Similarly, authors have advocated sandblasting the denture base to create a roughened surface to improve the adhesive bond. ${ }^{[9]}$

The present study was aimed to evaluate the effect of surface pre-treatment of denture bases with chemical, mechanical, and a combination of mechanochemical methods on the tensile bond strength of two different acrylic permanent resilient liners.

\section{MATERIALS AND METHODS}

The present in vitro study was conducted at the Department of Prosthodontics and Crown and Bridge, SVS Institute of Dental Sciences, Mahbubnagar and Indian Institute of Chemical Technology, Hyderabad, to evaluate the tensile bond strength of heat-polymerized acrylic soft liners with various surface pre-treatment of denture bases. The materials used for the study were Trevalon (powder and liquid) (Dentsply India Pvt. Ltd., Gurgaon, India), Permasoft Soft liner (Dentsply India Pvt., Ltd., Gurgaon, India), Acrasoft Soft liner (Henry Schein, USA), Lab putty (Lab Putty SilTech, LOT ML4139, Ivoclar Vivadent, Italy), Type III Stone (LOT 00601, Kalabhai Kanson Pvt. Ltd., Mumbai, India), MMA (Dentsply India Pvt. Ltd., Gurgaon, India), Sand $250 \mu \mathrm{m}$ (Bego, Wilhelm-Herbst, Germany), and Artificial saliva (Wet Mouth, ICPA Health Products Limited, India).
The method used in the study was divided into the following steps:

\section{Preparation of Die}

Eight brass bars of uniform dimensions $(40 \mathrm{~mm}$ $\mathrm{x} 10 \mathrm{~mm} \times 10 \mathrm{~mm}$ ) were fabricated for preparing the mold for the acrylic blocks [Figure 1]. A brass template was fabricated to orient and for providing $3 \mathrm{~mm}$ space for the soft liner [Figure 2].

\section{Preparation of the Acrylic Blocks}

The brass dies were invested with lab putty in the lower portion of the dental flask. After the putty was set, the second pour was done with Type III gypsum and flasking was completed. After the final set of the dental stone, the brass dies were retrieved.

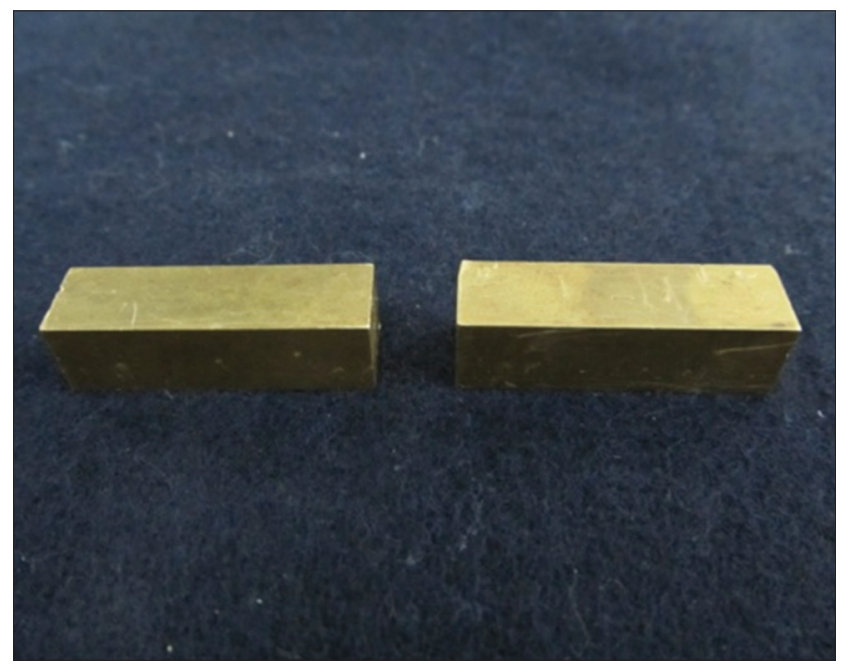

Figure 1: Brass dies

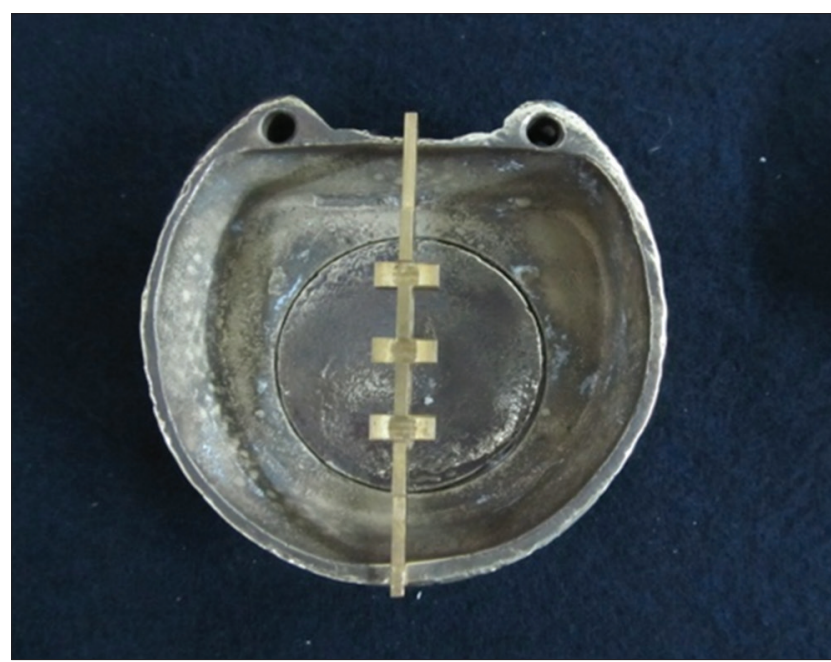

Figure 2: Brass template with flask 
The heat-cured PMMA acrylic resin was mixed in a porcelain jar using stainless steel spatula by maintaining the monomer: polymer ratio as 1:3 by volume, following the manufacturer's instructions. The acrylic resin was packed in the mold in dough stage and kept under hydraulic bench press under $2 \mathrm{~kg}$ static load for $10 \mathrm{~m}$. After bench curing for $1 \mathrm{~h}$, the flask assembly was placed in acrylizer and the temperature of water was raised from room temperature $24^{\circ} \mathrm{C} \pm 1^{\circ} \mathrm{C}$ to $74^{\circ} \mathrm{C}$ and maintained for $2 \mathrm{~h}$ followed by $100 \mathrm{C}$ for $1 \mathrm{~h} .{ }^{[10]}$ The flask assembly was allowed to bench cool. The acrylic blocks were retrieved and trimmed. 320 blocks were prepared following the same procedure.

\section{Grouping of Samples}

The 320 blocks were divided into two groups of 160 each and named as Group 1 (Permasoft) and Group 2 (Acrasoft). Each group was again subdivided into A, B, C, and D subgroups (40 each), depending on the type of surface treatment which would be performed.

\section{Surface Treatment}

One face $(10 \mathrm{~mm} \times 10 \mathrm{~mm})$ of each block was labeled, and the opposite face was treated as follows: Subgroup A: No surface treatment, Subgroup B: Chemical treatment, Subgroup C: Mechanical treatment, and Subgroup D: Mechanochemical treatment.

Chemical treatment was done by applying MMA with a cotton swab for $10 \mathrm{~s}$ [Figure 3]. In mechanical treatment, the surface was sandblasted with $250 \mu \mathrm{m}$ aluminum oxide at 0.06 mega pascals $(\mathrm{MPa})$ pressure for $30 \mathrm{~s}$ [Figure 4]. ${ }^{[8,9]}$ In mechanochemical treatment, the surface was sandblasted with $250 \mathrm{um}$ aluminum oxide at $0.06 \mathrm{MPa}$ pressure for 10 $\mathrm{s}$ followed by the application of MMA with a cotton swab for $10 \mathrm{~s}$. The scanning electron microscope view of the treated surface was observed [Figure 5].

\section{Preparation of the Specimens}

The acrylic blocks and the template were oriented and invested in the lower half of the dental flask with lab putty [Figure 6]. The surface treated ends of the blocks were kept facing each other. The second pour was done with type III gypsum and the flasking procedure was completed. After the final set of gypsum, the template was removed and the mold was ready to be packed with soft liner material. Group 1 blocks were packed with Permasoft material and group 2 blocks were packed with Acrasoft material. The soft liner material was

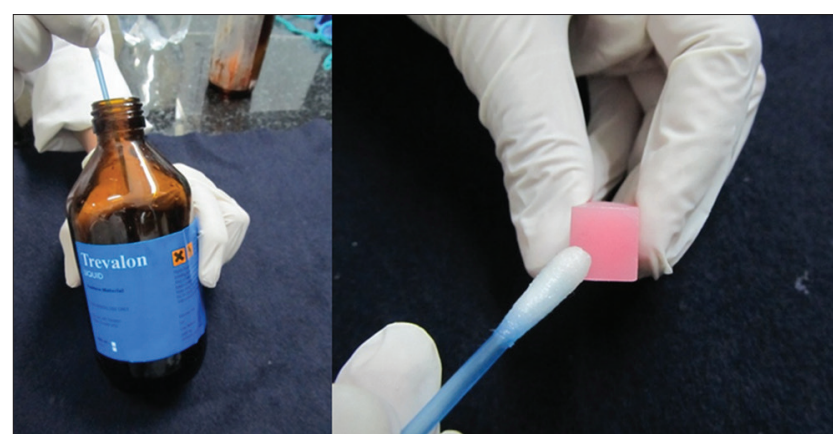

Figure 3: Chemical treatment of polymethyl methacrylate with monomer

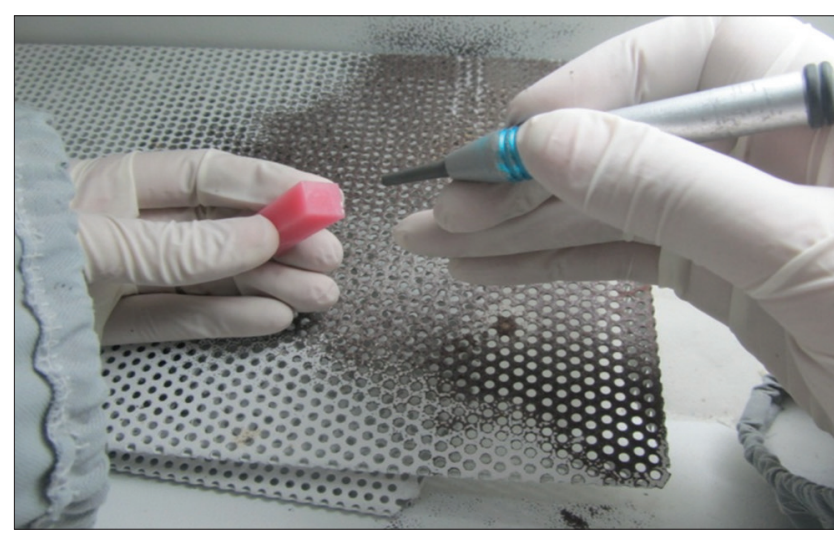

Figure 4: Mechanical treatment of polymethyl methacrylate blocks

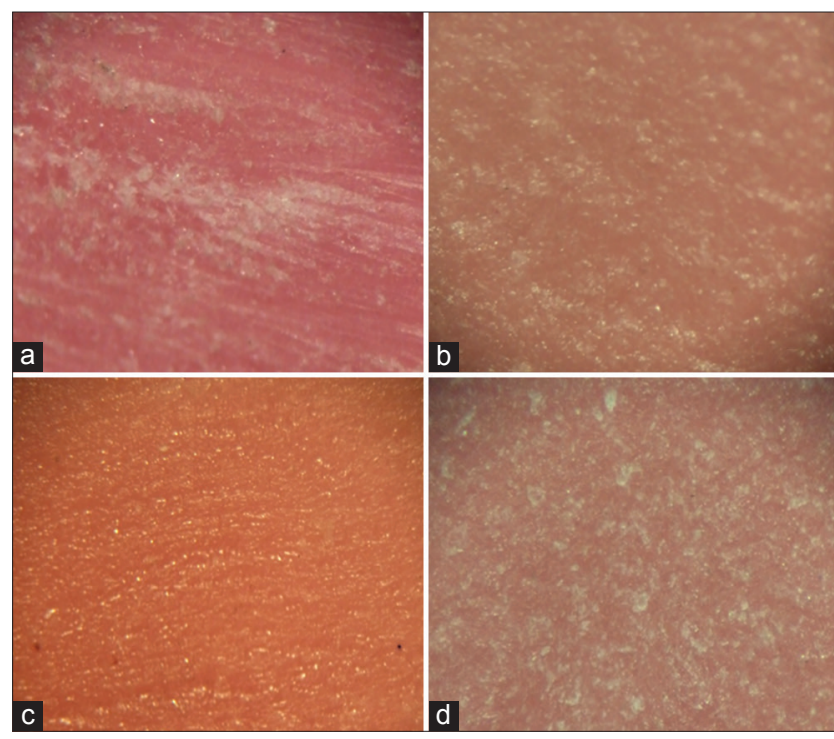

Figure 5: Stereo-microscopic views of polymethyl methacrylate blocks; (a) control; (b) chemical treatment; (c) Mechanical treatment and $(\mathrm{d})$ mechanochemical treatment

mixed in 1:4 ratio according to manufacturer's instructions, with a plastic spatula and packed into 
the mold [Figure 7], and placed in the hydraulic bench press for $15 \mathrm{~m}$. Then, curing was done by placing the flask assembly in acrylizer containing water at $95{ }^{\circ} \mathrm{C}$ for $15 \mathrm{~m}$. It was allowed to bench cool, and the specimens were retrieved. The excess material was cut with a sharp knife [Figure 8]. A total of 160 specimens were prepared following the same procedure. follows:

The specimens were labeled and numbered as

\begin{tabular}{lcccc}
\hline $\begin{array}{l}\text { Surface } \\
\text { treatment }\end{array}$ & \multicolumn{2}{c}{$\begin{array}{c}\text { Group I } \\
\text { (24 h group) }\end{array}$} & \multicolumn{2}{c}{$\begin{array}{c}\text { Group II } \\
\text { (1 month group) }\end{array}$} \\
\cline { 2 - 5 } & $\begin{array}{c}\text { Group 1 } \\
\text { (Permasoft) }\end{array}$ & Group 2 & Group 1 & Group 2 \\
& A1 (1-10) & A2 (41-50) & A3 (81-90) & A4 (121-130) \\
\hline Control & B1 (11-20) & B2 (51-60) & B3 (91-100) & B4 (131-140) \\
Chemical & C1 (21-30) & C2 (61-70) & C3 (101-110) & C4 (141-150) \\
Mechanical & (Permasoft) & Acrasoft) \\
Mechanochemical D1 (31-40) & D2 (71-80) & D3 (111-120) & D4 (151-160) \\
\hline
\end{tabular}

\section{Conditioning of the Specimens}

The specimens were immersed in distilled water for 24 h. ${ }^{[11]}$ Half of the specimens (10) from each subgroup were tested after $24 \mathrm{~h}$. The remaining specimens wereimmersed injars containing artificial saliva for 30 days. The artificial saliva was changed every 3 days to prevent fungal growth. Thermal cycling was done for these specimens to mimic the oral temperature conditions. The specimens were submitted to 3000 cycles, alternating with a $1-\mathrm{m}$ dwell time between $5^{\circ} \mathrm{C} \pm 1^{\circ} \mathrm{C}$ and $55^{\circ} \mathrm{C} \pm 1^{\circ} \mathrm{C} .^{[2]}$

\section{Testing of the Specimen}

The tensile bond strength was tested using a Universal Testing Machine (UTM), Shimadzu, AGS $10 \mathrm{kn}$ model. The two ends of the specimen were held between the grips of the testing assembly, after which command was given to UTM machine with the help of personal computer that was attached to the machine. Tensile bond strength testing was performed at a crosshead speed of $5 \mathrm{~mm} / \mathrm{min}$ with a gauge length of $5 \mathrm{~cm}$.

Bond strength was calculated as maximum load (N) divided by the cross-sectional area $\left(\mathrm{mm}^{2}\right)$ of the specimen and recorded in $\mathrm{MPa}$ as per the American Society for Testing and Materials (ASTM).

Tensile bond strength $=$ Load/Cross-sectional area.

The same procedure was repeated for all the specimens. Tensile bond strength was calculated, and the results obtained were statistically analyzed.

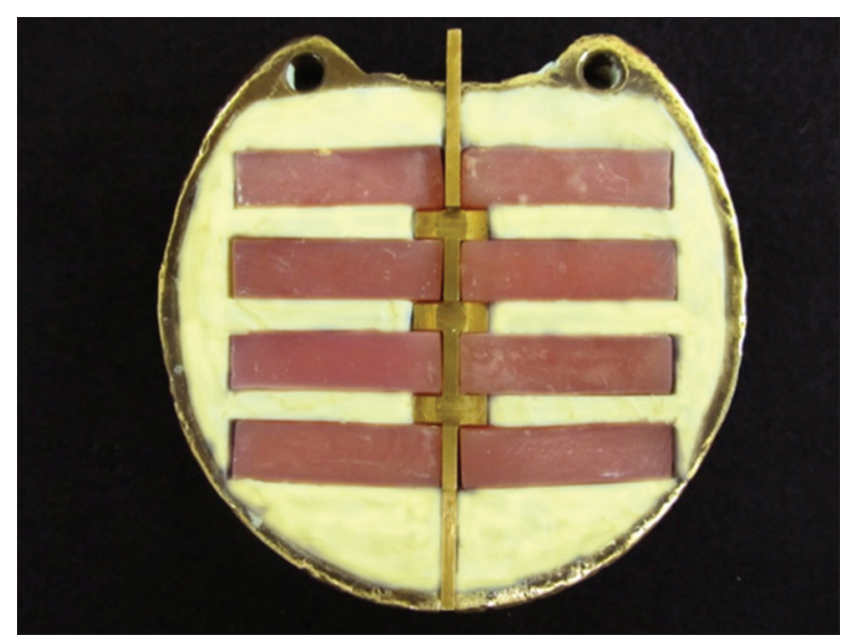

Figure 6: polymethyl methacrylate blocks invested with brass template in lab putty

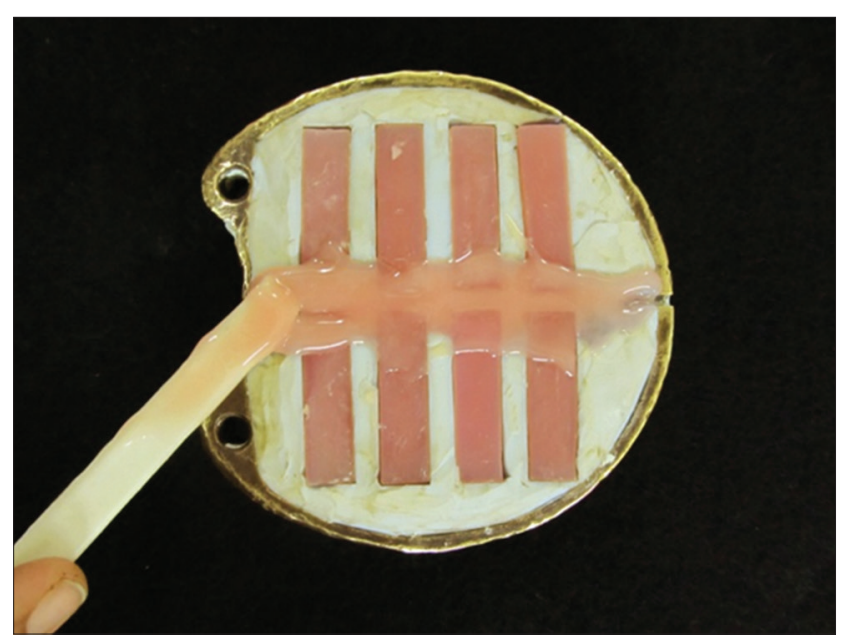

Figure 7: polymethyl methacrylate blocks lined with resilient denture liner

\section{RESULTS}

In the present study, tensile bond strength between denture base resin and acrylic resin soft liner was tested using UTM. The results obtained were tabulated and graphs were plotted, and the data were statically analyzed using SPSS software (Version 13, Chicago.2, USA) using oneway ANOVA. The means were compared using the Tukey (HSD) test. $P<0.05$ was considered statistically significant, $P<0.001$ was considered highly significant, and $P>0.05$ was considered not significant.

The highest mean tensile bond strength was found in Acrasoft mechanically treated $24 \mathrm{~h}$ group with a mean and standard deviation of $3.500 \pm$ 
0.170 , followed by Permasoft mechanically treated $24 \mathrm{~h}$ group and the least for Permasoft control 1-month group [Table 1 and Graph 1].

Between the two soft liners tested, Group 2 (Acrasoft) showed more tensile bond strength than the Group 1 (Permasoft) for all the treatment groups at both time periods. Statistically, a highly significant difference was observed for mechanical and mechanochemical treatment groups $(P<0.001)$, and no statistically significant difference was observed between the chemical treatment groups $(P>0.05)$ [Tables 2-4].

In comparison between the control and chemically treated groups, no statistically significant difference was found between the 1-month groups, but significant difference was observed between the 24-h groups [Table 5].

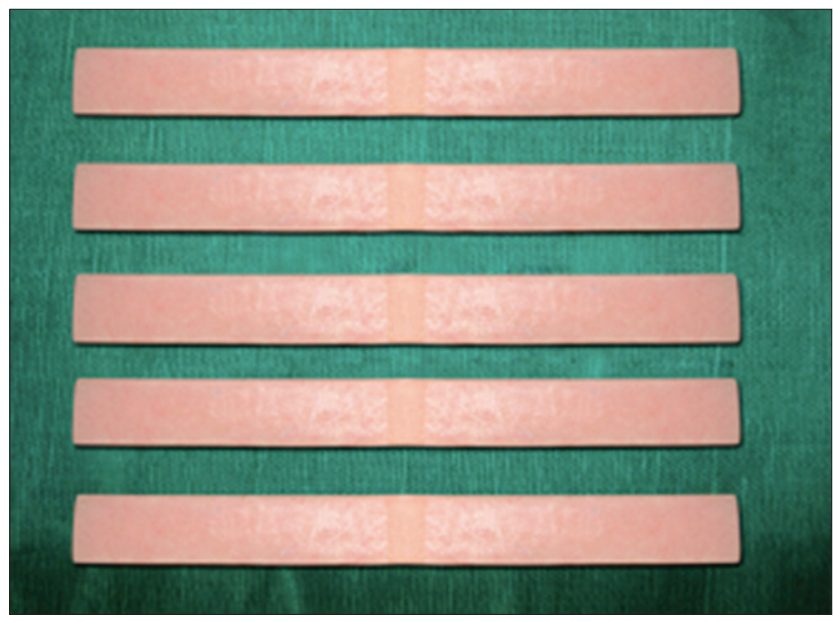

Figure 8: Final specimens with liner

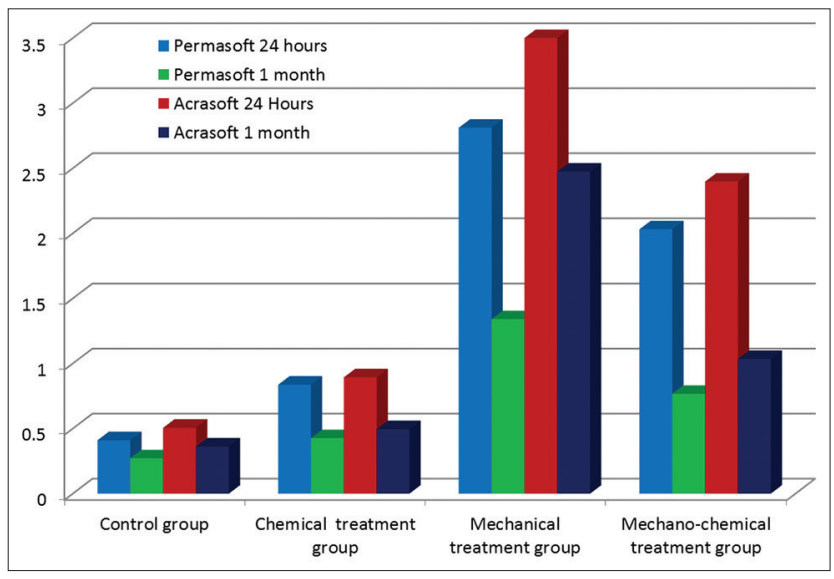

Graph 1: Comparison of tensile bond strength between all the groups for different surface pre-treatments
Highly statistically significant difference was found between the groups (control and mechanical and control and mechanochemical) at both time periods [Table 6 and 7].

\section{DISCUSSION}

The patient with chronic soreness caused by irritation from faulty dentures and bruxism or by denture irritation secondary to a systemic condition has difficulty in adjusting to prosthetic treatment. ${ }^{[12,13]}$ Denture soft lining materials play a key role in modern removable prosthodontics because of their capability of restoring the health of inflamed and distorted mucosa. ${ }^{[14,10,15]}$

However, one of the severe problems with resilient denture liners is bond failure between liner and denture base leading to microleakage, which in turn may promote bacterial growth, plaque, and calculus formation. Several factors may affect the

\begin{tabular}{lcccc}
\multicolumn{5}{l}{ Table 1: Mean of all the 16 subgroups } \\
Group & $\boldsymbol{N}$ & Range & Mean \pm SD & SEM \\
\hline A1 & 10 & $0.38-0.44$ & $0.410 \pm 0.020$ & 0.007 \\
B1 & 10 & $0.76-0.98$ & $0.837 \pm 0.067$ & 0.021 \\
C1 & 10 & $2.56-2.98$ & $2.811 \pm 0.173$ & 0.055 \\
D1 & 10 & $1.08-2.62$ & $2.030 \pm 0.403$ & 0.128 \\
A2 & 10 & $0.39-0.69$ & $0.506 \pm 0.099$ & 0.031 \\
B2 & 10 & $0.74-1.08$ & $0.893 \pm 0.115$ & 0.036 \\
C2 & 10 & $3.22-3.78$ & $3.500 \pm 0.170$ & 0.057 \\
D2 & 10 & $1.56-2.87$ & $2.397 \pm 0.393$ & 0.124 \\
A3 & 10 & $0.21-0.35$ & $0.272 \pm 0.045$ & 0.014 \\
B3 & 10 & $0.32-0.56$ & $0.426 \pm 0.075$ & 0.024 \\
C3 & 10 & $1.04-1.98$ & $1.340 \pm 0.319$ & 0.101 \\
D3 & 10 & $0.45-0.98$ & $0.767 \pm 0.153$ & 0.048 \\
A4 & 10 & $0.23-0.46$ & $0.362 \pm 0.082$ & 0.026 \\
B4 & 10 & $0.32-0.70$ & $0.495 \pm 0.123$ & 0.039 \\
C4 & 10 & $2.32-2.56$ & $2.474 \pm 0.082$ & 0.026 \\
D4 & 10 & $0.85-1.32$ & $1.035 \pm 0.118$ & 0.037 \\
\hline
\end{tabular}

SD: Standard deviation, SEM: Standard error of the mean

Table 2: Intergroup comparison of chemical treatment subgroups at $24 \mathrm{~h}$ and 1 month

\begin{tabular}{lccc} 
Time of & \multicolumn{2}{c}{ Mean \pm SD } & $P$ \\
\cline { 2 - 3 } testing & Permasoft B1 & Acrasoft B2 & \\
\hline 24 h & $0.83 \pm 0.66$ & $0.89 \pm 0.11$ & $1.000 \mathrm{NS}$ \\
& B3 & B 4 & \\
1 month & $0.42 \pm 0.74$ & $0.49 \pm 0.12$ & $1.000 \mathrm{NS}$
\end{tabular}

SD: Standard deviation, $P>0.05$, NS: non significant 
bond strength between the resilient lining material and the denture base, such as aging in water, use of adhesive, and the nature of the denture base material.

In the present study, the tensile bond strength was tested between the denture base resin and two acrylic soft liners. Even though the longevity of silicone denture liners is more when compared to acrylic liners, their major disadvantage is the bond failure between the liner and denture base material because of the adhesive bonding. However, acrylic liners show cohesive bonding with denture base resins, which is superior to the silicone liners. ${ }^{[16]}$

The specimens in this study were placed in artificial saliva to simulate oral environmental conditions, and tensile bond strength was evaluated

Table 3: Intergroup comparison of mechanical treatment subgroups at $24 \mathrm{~h}$ and 1 month

\begin{tabular}{lccc} 
Time of & \multicolumn{2}{c}{ Mean \pm SD } & $P$ \\
\cline { 2 - 3 } testing & Permasoft C1 & Acrasoft C2 & \\
\hline $24 \mathrm{~h}$ & $2.8 \pm 0.17$ & $3.5 \pm 0.16$ & $<0.001^{* *}$ \\
& $\mathrm{C} 3$ & $\mathrm{C} 4$ & \\
1 month & $1.3 \pm 0.31$ & $2.4 \pm 0.08$ & $<0.001^{* *}$ \\
\hline
\end{tabular}

SD: Standard deviation. ${ }^{*} P<0.001$ highly significant

\section{Table 4: Intergroup comparison of mechanochemical} treatment subgroups at $24 \mathrm{~h}$ and 1 month

\begin{tabular}{lccc}
\multirow{2}{*}{$\begin{array}{l}\text { Time of } \\
\text { testing }\end{array}$} & \multicolumn{2}{c}{ Mean \pm SD } & $P$ \\
\cline { 2 - 3 } & Permasoft D1 & Acrasoft D2 & \\
\hline $24 \mathrm{~h}$ & $2.0 \pm 0.40$ & $2.3 \pm 0.39$ & $0.003^{*}$ \\
& $\mathrm{D} 3$ & $\mathrm{D} 4$ & \\
1 month & $0.76 \pm 0.15$ & $1.0 \pm 0.11$ & $<0.001^{* *}$ \\
\hline $\begin{array}{l}\text { SD: Standard deviation, }{ }^{*} P<0.05 \\
\text { highly statistically significant, } * * P<0.001\end{array}$
\end{tabular}

over varying intervals of time ( $24 \mathrm{~h}$ and 1 month). Soft liners are in saliva during clinical use, and they may be soaked in an aqueous cleaning solution or water during storage of the denture. When immersed, soft lining materials undergo two processes: Plasticizers and other soluble materials are leached out and water or saliva is absorbed. ${ }^{[17]}$ Both processes are important as they are going to have an impact on the physical and mechanical properties of the material.

The change of temperature with hot or cold foods in the mouth may also affect the mechanical properties and bonding strength of soft liner. In the present study, 3000 cycles of thermocycling was done to simulate the same. ${ }^{[2]}$ The mechanical properties of soft relining materials and their bonding characteristics have been evaluated by various test methods. There are three widely accepted methods for testing adhesion of denture soft liners to denture base polymers: Peel, lap shear, and tensile testing. ${ }^{[18]}$ Testing the soft liners using peel testing is believed to be the finest simulation of the clinical setting for the soft lining material failure. However, the results obtained from peel test were reported to be unsatisfactory due to the probability of cohesive failures of the soft liner materials. In lap and shear testing, the stresses applied to the specimen are believed to be concentrated at the edges of lining material,making interpretation of bond strength results difficult. Tensile bond tests have been shown to develop more meaningful measurements of the strength of the interface compared with the strength of the material. ${ }^{[19]}$ This method was described by the ASTM. ${ }^{[18]}$

The results of the present study reveal that, between the two soft liners tested, Group 2 (Acrasoft) showed more tensile bond strength

\section{Table 5: Comparison of control groups with chemical treatment groups}

\begin{tabular}{|c|c|c|c|}
\hline \multirow[t]{2}{*}{ Tested group } & \multicolumn{2}{|c|}{ Mean \pm SD } & \multirow[t]{2}{*}{$\boldsymbol{P}$} \\
\hline & Control group & Chemically treated group & \\
\hline \multirow[t]{2}{*}{ Permasoft $24 \mathrm{~h}$ group } & $\mathrm{A} 1$ & B1 & $<0.001^{* *}$ \\
\hline & $0.41 \pm 0.20$ & $0.83 \pm 0.66$ & \\
\hline \multirow[t]{2}{*}{ Permasoft 1 month group } & A3 & B3 & $0.908 \mathrm{NS}$ \\
\hline & $0.27 \pm 0.45$ & $0.42 \pm 0.74$ & \\
\hline \multirow[t]{2}{*}{ Acrasoft $24 \mathrm{~h}$ group } & $\mathrm{A} 2$ & B2 & $0.001^{*}$ \\
\hline & $0.50 \pm 0.98$ & $0.89 \pm 0.11$ & \\
\hline \multirow[t]{2}{*}{ Acrasoft 1 month group } & $\mathrm{A} 4$ & B4 & $0.978 \mathrm{NS}$ \\
\hline & $0.36 \pm 0.81$ & $0.41 \pm 0.12$ & \\
\hline
\end{tabular}

SD: Standard deviation, $P>0.05$ non significant, $* P<0.05$ statistically significant, $* * P<0.001$ highly significant 


\begin{tabular}{|c|c|c|c|}
\hline \multirow[t]{2}{*}{ Tested group } & \multicolumn{2}{|c|}{ Mean \pm SD } & \multirow[t]{2}{*}{$\boldsymbol{P}$} \\
\hline & Control group & Mechanically treated group & \\
\hline \multirow[t]{2}{*}{ Permasoft 24 h group } & $\mathrm{A} 1$ & $\mathrm{C} 1$ & $<0.001^{* *}$ \\
\hline & $0.41 \pm 0.20$ & $2.8 \pm 0.17$ & \\
\hline \multirow[t]{2}{*}{ Permasoft 1 month group } & A3 & $\mathrm{C} 3$ & $<0.001^{* *}$ \\
\hline & $0.27 \pm 0.45$ & $1.3 \pm 0.31$ & \\
\hline \multirow[t]{2}{*}{ Acrasoft $24 \mathrm{~h}$ group } & $\mathrm{A} 2$ & $\mathrm{C} 2$ & $<0.001 * *$ \\
\hline & $0.50 \pm 0.98$ & $3.5 \pm 0.16$ & \\
\hline \multirow[t]{2}{*}{ Acrasoft 1 month group } & $\mathrm{A} 4$ & $\mathrm{C} 4$ & $<0.001^{* *}$ \\
\hline & $0.36 \pm 0.81$ & $2.4 \pm 0.08$ & \\
\hline
\end{tabular}

SD: Standard deviation. $* * P<0.001$ highly significant

Table 7: Comparison of control groups with mechanochemical treatment groups

\begin{tabular}{|c|c|c|c|}
\hline \multirow[t]{2}{*}{ Tested group } & \multicolumn{2}{|c|}{ Mean \pm SD } & \multirow[t]{2}{*}{$\boldsymbol{P}$} \\
\hline & Control group & Mechanochemical treated group & \\
\hline \multirow[t]{2}{*}{ Permasoft 24 h group } & A1 & D1 & $<0.001^{* *}$ \\
\hline & $0.41 \pm 0.20$ & $2.0 \pm 0.40$ & \\
\hline \multirow[t]{2}{*}{ Permasoft 1 month group } & A3 & D3 & $<0.001^{* *}$ \\
\hline & $0.27 \pm 0.45$ & $0.76 \pm 0.15$ & \\
\hline \multirow[t]{2}{*}{ Acrasoft 24 h group } & $\mathrm{A} 2$ & D2 & $<0.001^{* *}$ \\
\hline & $0.50 \pm 0.98$ & $2.3 \pm 0.39$ & \\
\hline \multirow[t]{2}{*}{ Acrasoft 1 month group } & A4 & D4 & $<0.001^{* *}$ \\
\hline & $0.36 \pm 0.81$ & $1.0 \pm 0.11$ & \\
\hline
\end{tabular}

SD: Standard deviation. ${ }^{* *} P<0.001$ highly significant

than the Group 1 (Permasoft) for all the treatment groups at both time periods compared to control group. Statistically, a highly significant difference was observed for mechanical and mechanochemical treatment groups $(P<0.001)$ [Tables 5-7], and no statistically significant difference was observed between the chemical treatment groups $(P>0.05)$.

Between the two time periods $(24 \mathrm{~h}$ and 1 month), tensile bond strength was found to be more for 24-h group for both the materials after various pre-treatments compared to that of 1 month with a statistically highly significant value $(P<0.001)$. The material becomes harder with time. It is likely that leaching of plasticizers from the acrylic resin material is responsible for its hardening during clinical use. This may result in warpage of the resilient liners and decrease in bond strength after the 1 month period. ${ }^{[3]}$ When the resilient lining material absorbs water, stress occurs between the bonding surfaces and viscoelastic properties of the resilient liners change. The material becomes brittle and transfers the external loads to the bond area.
Probably due to these causes, the specimens stored for 1-month period showed less bond strength when compared to $24 \mathrm{~h}$ specimens.

The results of the present study revealed that the various surface pre-treatment protocols used significantly improved the tensile bond strength between the liner and the denture base. The results of this study support the hypothesis that chemical and mechanical pre-treatment improved the tensile bond strength of the acrylic resilient liner to the denture base. ${ }^{[5,20]}$ The control group showed significantly lower bond strength than the surface pre-treated experimental groups $(P<0.001)$.

Among the three methods of pre-treatment of denturebase resins, it wasinferred that the Subgroup $\mathrm{C}$ (mechanical) pre-treatment method with sandblasting resulted in superior bond strength with resilient liner followed by Subgroup D (mechanochemical) and Subgroup B (chemical), respectively.

The superior bond strength of mechanical group specimens may be because of the surface roughness. 
When the pre-treated specimens were examined under stereo electron microscope, there was more surface roughness in mechanically treated group specimens compared to other groups, and hence, this leads to more retentive tags which further enhanced bonding of liner material to denture base material. This is in accordance with the results of the study done by Craig and Gibsons. ${ }^{[9]}$

In the mechanochemical-treated specimens probably, the roughness created was smoothened when it was wiped with monomer. This was inferred in the stereo electron microscope study.

\section{Limitations of the Study}

This study evaluated tensile bond strength between liner and denture base immersed in artificial saliva over $24 \mathrm{~h}$ and 1 month. However, the behavior of bonding between permanent denture soft liner and pre-treated denture base resin must have been assessed over a longer period of time to assess the efficacy in a broader spectrum.

The present study is an in vitro study, and hence, some variations might be experienced when tested under in vivo conditions owing to the presence of serum markers and immunoglobulin's in the saliva, mouth temperature, varying concentrations of ions in the saliva, fluctuations in the $\mathrm{pH}$ of saliva, different occlusal schemes, use of disinfectants, and stain removers during denture maintenance. These factors could modify bond strength during functions.

The various pre-treatments may show different results when tested with the silicone lining materials.

\section{CONCLUSION}

Within the limitations of this study, the following conclusions can be drawn:

1. The surface pre-treatment of denture base resins significantly increased the tensile bond strength and adhesive capacity with heat-cured MMA resilient liners.

2. Among the three methods of pre-treatment of denture base resin (chemical, mechanical, and mechanochemical) and subsequent exposure for varying time intervals in artificial saliva, Subgroup C (mechanical surface pre-treatment with sandblasting) exhibited superior bond strength over the other two methods.

3. The tensile bond strength between the denture base resin and the liner material subsequently decreased after immersion in artificial saliva over a time period.
4. Group 2 (Acrasoft) exhibited greater tensile bond strength with the denture base resin than Group 1 (Permasoft).

\section{REFERENCES}

1. Sauer JL. A clinical evaluation of silastic 390 as a lining material for dentures. J Prosthet Dent 1966;16:650-60.

2. León BL, Del Bel Cury AA, Rodrigues Garcia RC. Water sorption, solubility, and tensile bond strength of resilient denture lining materials polymerized by different methods after thermal cycling. J Prosthet Dent 2005;93:282-7.

3. Pinto JR, Mesquita MF, Nóbilo MA, Henriques GE. Evaluation of varying amounts of thermal cycling on bond strength and permanent deformation of two resilient denture liners. J Prosthet Dent 2004;92:288-93.

4. Saraç YS, Ba o lu T, Ceylan GK, Saraç D, Yapici O. Effect of denture base surface pretreatment on microleakage of a silicone-based resilient liner. J Prosthet Dent 2004;92:283-7.

5. Sarac D, Sarac YS, Basoglu T, Yapici O, Yuzbasioglu E. The evaluation of microleakage and bond strength of a silicone-based resilient liner following denture base surface pretreatment. J Prosthet Dent 2006;95:143-51.

6. Braden M, Causton BE. Tissue conditioners 3. Water immersion characteristics. J Dent Res 1971;50:1544-7.

7. Starcke EN Jr., Marcroft KR, Fischer TE, Sweeney WT. Physical properties of tissue-conditioning materials as used in functional impressions. J Prosthet Dent 1972;27:111-9.

8. Vallittu PK, Lassila VP, Lappalainen R. Wetting the repair surface with methyl methacrylate affects the transverse strength of repaired heat-polymerized resin. J Prosthet Dent 1994;72:639-43.

9. Craig RG, Gibbons P. Properties of resilient denture liners. J Am Dent Assoc 1961;63:382-90.

10. Polyzois GL. Adhesion properties of resilient lining materials bonded to light-cured denture resins. J Prosthet Dent 1992;68:854-8.

11. Hayakawa I, Hirano S, Takahashi Y, Keh ES. Changes in the masticatory function of complete denture wearers after relining the mandibular denture with a soft denture liner. Int J Prosthodont 2000;13:227-31.

12. Garcia RM, Léon BT, Oliveira VB, Del Bel Cury AA. Effect of a denture cleanser on weight, surface roughness, and tensile bond strength of two resilient denture liners. J Prosthet Dent 2003;89:489-94.

13. Yilmaz H, Aydin C, Bal BT, Ocak F. Effects of different disinfectants on physical properties of four temporary soft denture-liner materials. Quintessence Int 2004;35:826-34.

14. Graham BS, Jones DW, Sutow EJ. An in vivo and in vitro study of the loss of plasticizer from soft polymer-gel materials. J Dent Res 1991;70:870-3.

15. Hayakawa I, Akiba N, Keh E, Kasuga Y. Physical properties of a new denture lining material containing a fluoroalkyl methacrylate polymer. J Prosthet Dent 2006;96:53-8.

16. Aníl N, Hekimoglu C, Büyükbas N, Ercan MT. Micro leakage study of various soft denture liners by autoradiography: 
Effect of accelerated aging. J Prosthet Dent 2000;84:394-9.

17. Cucci AL, Vergani CE, Giampaolo ET, Afonso MC. Water sorption, solubility, and bond strength of two auto polymerizing acrylic resins and one heat-polymerizing acrylic resin. J Prosthet Dent 1998;80:434-8.

18. Kutay O. Comparison of tensile and peel bond strengths of resilient liners. J Prosthet Dent 1994;71:525-31.
19. Bates JF, Smith DC. Evaluation of indirect resilient liners for dentures: Laboratory and clinical tests. J Am Dent Assoc 1965;70:344-53.

20. Can G, Tonguc O, Usanmaz A. Effect of thermo cycling and treatment with monomer on mechanical properties of soft denture liner molloplast B. Int J Adhes Adhes 2009;29:812-4. 